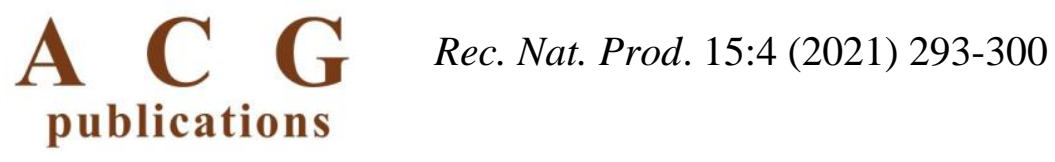

\title{
New Flavonoids from Saudi collection of Tephrosia purpurea L. (Pers.)
}

\section{Maged S. Abdel-Kader $\odot{ }^{1,2^{*}}$ Mohammed H. Alqarni $\odot{ }^{1}$ and Ahmed I. Foudah ${ }^{1}$}

\author{
${ }^{I}$ Department of Pharmacognosy, College of Pharmacy, Prince Sattam Bin Abdulaziz University, P.O. \\ Box 173, Al-Kharj 11942, Saudi Arabia \\ ${ }^{2}$ Department of Pharmacognosy, Faculty of Pharmacy, Alexandria University, Alexandria 21215, \\ Egypt
}

(Received October 01, 2020; Revised December 10, 2020; Accepted December 12, 2020)

\begin{abstract}
Phytochemical investigation of the chloroform fraction obtained from Saudi collection of Tephrosia purpurea L. (Pers.) resulted in the isolation of four new and two known flavonoid derivatives. Three of the new compounds were 5-deoxyflavonoid derivatives identified as tephropurpugazanin (1), 4"-hydroxyapollinin (4), epi-tephroapollin E (5) as well as (-)-tephropurpulin A (2). The known compounds were identified as 3,7dihydroxy-8-methoxy-2-(4-methoxyphenyl)-4H-1-benzopyran-4-one (3) and tephroapollin E (6). Structures were elucidated utilizing different spectroscopic tools including UV, optical rotation, 1D- and 2D-NMR as well as HRESIMS.
\end{abstract}

Keywords: Tephrosia purpurea; isolation; structure elucidation; 5-deoxyflavonoid. @ 2021 ACG Publications. All rights reserved.

\section{Introduction}

The plant Tephrosia purpurea Family Fabaceae is traditionally used for the treatment of many ailments including malaria, wounds, gastro-duodenal, kidney, liver and heart disorders [1-2] Extracts from different parts of $T$. purpurea showed antimicrobial, antidiabetic, antiurolithiatic, anticancer, wound healing and hepatoprotective effects [3-8]. Flavonoid glycoside fraction from T. purpurea exhibited insecticidal activity [9]. Prenylated flavones isolated from the aerial parts of the plant showed acetylcholine esterase inhibitory activity and neuroprotective effect [10]. Four prenylated flavones from the stems of $T$. purpurea reported to have antiplasmodial activity against Plasmodium falciparum with $(E)$-5-hydroxytephrostachin being the most active [11]. Terpurinflavone showed antiplasmodial activity against both chloroquine- sensitive and resistant Plasmodium falciparum [12]. Flavones from the plant stems also proved to possess diuretic effect [13].

Prenylated flavonoids are the most predominant secondary metabolites in the genus and can serve as biomarkers for species that exceed 350 in the genus [14-15]. In the current study we reported on the isolation and characterization of four new prenylated flavonoid derivatives from the entitled plant.

\footnotetext{
*Corresponding author: E-Mail: mpharm101@ @otmail.com
} 


\section{Materials and Methods}

\subsection{General}

Melting points were determined in open capillary tubes using a Thermosystem FP800 Mettler FP80 central processor supplied with an FP81 MBC cell apparatus and are uncorrected. Ultraviolet absorptions spectra were measured on a Unicum Heyios a UV-Visible spectrophotometer. Jasco P2000 Polarimeter was used to measure the optical rotations and CD spectra were recorded using Jasco J-815 spectrometer (College of Pharmacy, King Saud University). ${ }^{1} \mathrm{H},{ }^{13} \mathrm{C}-\mathrm{NMR}$ and 2D-NMR data were collected on a Bruker UltraShield Plus $500 \mathrm{MHz}$ spectrometer at the NMR Unite, College of Pharmacy, Prince Sattam Bin Abdulaziz operated at $500 \mathrm{MHz}$ for protons and $125 \mathrm{MHz}$ for carbon atoms, respectively. The instrument is equipped with analytical probe using $1.7 \mathrm{X} 103.5 \mathrm{~mm}$ tubes. Chemical shift values were reported in $\delta(\mathrm{ppm})$ relative to the residual solvents peaks. Coupling constants (J) were reported in Hertz (Hz). 2D-NMR experiments (COSY, HSQC, HMBC, H2BC, NOESY and/or ROESY) were performed utilizing the standard Bruker program. HRMS were determined by direct injection using Thermo Scientific UPLC RS Ultimate 3000 - Q Exactive hybrid quadrupole-Orbitrap mass spectrometer combines high performance quadrupole precursor selection with high resolution, accurate-mass (HR/AM) Orbitrap ${ }^{\mathrm{TM}}$ detection. Direct Infusion of isocratic elution Acetonitrile/Methanol (70:30) with $0.1 \%$ formic acid was used to flush the samples. Runtime was $1 \mathrm{~min}$ using nitrogen as auxiliary gas with flow rate $5 \mu \mathrm{l} / \mathrm{min}$. Scan range from $160-1500 \mathrm{~m} / z$ was used. Resolving Power was adjusted to 70,000 @ m/z 200. Detection was in both positive and negative modes separately. Calibration was done using Thermo Scientific Pierce ${ }^{\mathrm{TM}}$ LTQ Velos ESI Positive Ion Calibration Solution including Caffeine, Met-Arg-Phe-Ala (MRFA), Ultramark 1621, n-Butyl-amine components and Pierce ${ }^{\mathrm{TM}}$ LTQ Velos ESI. Negative Ion Calibration Solution includes sodium dodecyl sulphate (SDS), sodium taurocholate, Ultramark 1621components. Capillary temperature set at $320{ }^{\circ} \mathrm{C}$ and capillary voltage at $4.2 \mathrm{Kv}$. Sephadex LH-20 (Amersham Biosciences, Uppsala, Sweden), silica gel 60/230-400 mesh (EM Science), RP C-18 silica gel 40-63/230-400 mesh (Fluka) were used for column chromatography. The thin layer chromatography (TLC) analysis was performed on Kiesel gel 60 F254 and RP-18 F254 (Merck) plates. A UV lamp (entela Model UVGL-25) operated at $254 \mathrm{~nm}$ was used for detecting spots on the TLC plates.

\subsection{Plant Materials}

Plants of Tephrosia purpurea L. (Pers.) were collected in November, 2019 from Gazan province, Southern Saudi Arabia. The plants were identified by Dr. Mohammad Atiqur Rahman, taxonomist of the MAPPRC, College of Pharmacy, King Saud University, Riyadh, Saudi Arabia. A voucher specimen (\# MAPPRC 10548) preserved at the herbarium of the Medicinal, Aromatic and Poisonous Plants Research Center (MAPPRC).

\subsection{Extraction and Isolation}

Air-dried powdered aerial parts $(790 \mathrm{~g})$ were repeatedly extracted with $95 \%$ ethanol by percolation at room temperature till exhaustion. The solvent was distilled off using rotary vacuum evaporator at $40{ }^{\circ} \mathrm{C}$ to give $53 \mathrm{~g}$ residue. Part of the obtained dried extract was dissolved in $800 \mathrm{~mL}$ of $40 \%$ aqueous ethanol and fractionated with light petroleum $(500 \mathrm{~mL} \times 3)$ to yield $13.45 \mathrm{~g}$ petroleum ether soluble fraction, chloroform $(500 \mathrm{~mL} \times 4)$ to yield $14.12 \mathrm{~g}$ of chloroform soluble fraction, ethyl acetate $(400 \mathrm{~mL} \times 2)$ to yield $23.30 \mathrm{~g}$ of ethyl acetate soluble fraction and the left aqueous layer were freeze dried to yield $0.4 \mathrm{gm}$.

Part of the chloroform soluble fraction (12 g) was fractionated over silica gel column $(150 \times 5 \mathrm{~cm}$ i.d., $300 \mathrm{~g})$ eluting with chloroform followed by chloroform/methanol mixtures with gradual increase in methanol contents. Fractions of $200 \mathrm{~mL}$ each were collected, screened by TLC and similar fractions were pooled. Fractions eluted with chloroform $(0.4 \mathrm{~g})$ were purified over RP18 MPLC (45 cm X $1 \mathrm{~cm}$ id) eluting with $40 \%$ water in methanol with increasing methanol contents in a 
gradient system till 100\% methanol. Fractions 16-22 (49 mg) were subjected to PTLC using normal silica gel plates and chloroform/methanol (9.5:0.5) developing system to obtain $9 \mathrm{mg}$ of $\mathbf{1}$. Fractions $30-45(65 \mathrm{mg})$ were subjected to PTLC using normal silica gel plates and chloroform/methanol (9.5:0.5) as mobile phase (double development) to obtain $11 \mathrm{mg}$ of 2. Fractions 50-55 (35 mg) were subjected to PTLC using normal silica gel plates and chloroform/methanol (9.5:0.5) as mobile phase (double development) to obtain $6 \mathrm{mg}$ of $\mathbf{3}$.

Fractions eluted with $5 \%$ methanol in chloroform $(0.5 \mathrm{~g})$ were purified over silica gel column (45 $\mathrm{cm} \mathrm{X} 1 \mathrm{~cm}$ id, $40 \mathrm{gm}$ ) eluting with $25 \%$ ethyl acetate in petroleum ether with increasing the contents of ethyl acetate in a gradient system. Fractions eluted with $25 \%$ ethyl acetate $(80 \mathrm{mg})$ afforded $35 \mathrm{mg}$ of $\mathbf{4}$ on crystallization from methanol. Fractions eluted with $30 \%$ ethyl acetate (100 $\mathrm{mg}$ ) were purified over RP18 column (30 cm X $1 \mathrm{~cm}$ id, $15 \mathrm{gm})$ eluting with $35 \%$ water in methanol to afford $42 \mathrm{mg}$ of 5 after crystallization from methanol. Fractions eluted with $40 \%$ of ethyl acetate (52 $\mathrm{mg}$ ) were subjected to PTLC using silica gel plates and chloroform/methanol (9:1) to obtain $6 \mathrm{mg}$ of $\mathbf{6}$.

\subsection{Compounds Characterization}

Tephropurpugazanin (1): White powder; UV $\lambda_{\max } \mathrm{MeOH}: 242,250,315 \mathrm{~nm} ;{ }^{1} \mathrm{H}$ and ${ }^{13} \mathrm{C}$ NMR see Tables 1 and 2; HRESIMS [M+1] ${ }^{+} \mathrm{m} / z 337.1064$ (calcd for $\mathrm{C}_{20} \mathrm{H}_{17} \mathrm{O}_{5}+\mathrm{H}, 337.1076$ ), $[\mathrm{M}+\mathrm{Na}]^{+} \mathrm{m} / \mathrm{z}$ 359.0882 (calcd for $\mathrm{C}_{20} \mathrm{H}_{17} \mathrm{O}_{5}+\mathrm{Na}, 359.0895$ ), [M-1 $]^{+} \mathrm{m} / z 335.0935$ (calcd for $\mathrm{C}_{20} \mathrm{H}_{17} \mathrm{O}_{5}-\mathrm{H}, 335.0919$ ).

(-)-Tephropurpulin A (2): White powder; m.p $148.7{ }^{\circ} \mathrm{C} ;[\alpha]^{25} \mathrm{D}-304$; $\mathrm{CD}[\theta]_{309}+599,[\theta]_{298} 0,[\theta]_{271}-$ 3601, $[\theta]_{246} 0$; UV $\lambda_{\max } \mathrm{MeOH}: 251,285,321 \mathrm{~nm} ;{ }^{1} \mathrm{H}$ and ${ }^{13} \mathrm{C}$ NMR see Tables 1 and 2; HRESIMS $[\mathrm{M}+1]^{+} m / z, 411.1436$ (calcd for $\mathrm{C}_{23} \mathrm{H}_{22} \mathrm{O}_{7}+\mathrm{H}, 411.1444$ ).

4 "-Hydroxyapollinin (4): White powder; m.p $280.4{ }^{\circ} \mathrm{C}$; UV $\lambda_{\max } \mathrm{MeOH}: 245,252,319 \mathrm{~nm} ;{ }^{1} \mathrm{H}$ and ${ }^{13} \mathrm{C}$ NMR see Tables 1 and 2; HRESIMS $[\mathrm{M}+1]^{+} \mathrm{m} / z 379.1172$ (calcd for $\mathrm{C}_{22} \mathrm{H}_{18} \mathrm{O}_{6}+\mathrm{H}, 379.1182$ ), $[\mathrm{M}+\mathrm{Na}]^{+} \mathrm{m} / z$ 401.0995 (calcd for $\mathrm{C}_{22} \mathrm{H}_{18} \mathrm{O}_{6}+\mathrm{Na}, 401.1001$ ), [M-1] ${ }^{+} \mathrm{m} / z .377 .1025$ (calcd for $\mathrm{C}_{22} \mathrm{H}_{18} \mathrm{O}_{6^{-}}$ $\mathrm{H}, 377.1025$ ), $[\mathrm{M}+1-16]^{+} \mathrm{m} / \mathrm{z}, 363.1220$ (calcd for $\mathrm{C}_{22} \mathrm{H}_{18} \mathrm{O}_{5}+\mathrm{H}, 363.1232$ ), $[\mathrm{M}+\mathrm{Na}-16]^{+} \mathrm{m} / z .385 .1038$ (calcd for $\mathrm{C}_{22} \mathrm{H}_{18} \mathrm{O}_{5}+\mathrm{Na}, 385.1052$ ).

epi-Tephroapollin E (5): White powder; m.p $165.7^{\circ} \mathrm{C}$; $[\alpha]^{25} \mathrm{D}+94$; $\mathrm{CD}[\theta]_{273}+2606$, $[\theta]_{258}+3408$; UV $\lambda_{\max } \mathrm{MeOH}: 251,284,318 \mathrm{~nm} ;{ }^{1} \mathrm{H}$ and ${ }^{13} \mathrm{C}$ NMR see Tables 1 and 2; HRESIMS $[\mathrm{M}+1]^{+} \mathrm{m} / z$ 353.1381 (calcd for $\mathrm{C}_{21} \mathrm{H}_{20} \mathrm{O}_{5}+\mathrm{H}, 353.1389$ ), $[\mathrm{M}+\mathrm{Na}]^{+} \mathrm{m} / z, 375.1198$ (calcd for $\mathrm{C}_{21} \mathrm{H}_{20} \mathrm{O}_{5}+\mathrm{Na}, 375.1208$ ), [M-1] ${ }^{+}$ $m / z 351.1220$ (calcd for $\mathrm{C}_{21} \mathrm{H}_{20} \mathrm{O}_{5}-\mathrm{H}, 351.1232$ ).

Tephroapollin E (6): CD $[\theta]_{331}+1201,[\theta]_{308} 0,[\theta]_{259}-3792,[\theta]_{237} 0$

Acetylation of Tephroapollin E (6): Two mg of 6 were dissolved in $200 \mu \mathrm{L}$ of pyridine and $50 \mu \mathrm{L}$ of acetic anhydride were added. The reaction mixture was kept at room temperature for $24 \mathrm{hr}$ and then left to dry in hood to afford 6a. ${ }^{1} \mathrm{H}$ and ${ }^{13} \mathrm{C}$ NMR see Tables 1 and 2.

\section{Results and Discussion}

\subsection{Structure Elucidation}

The NMR data (Tables 1,2) indicated that compounds of $\mathbf{1 - 6}$ share 7, 8-disubstituted flavone skeleton. The ${ }^{1} \mathrm{H}-\mathrm{NMR}$ indicated the presence of 5 aromatic overlapped protons in the range $\delta_{\mathrm{H}} 7.27$ $7.93 \mathrm{ppm}$ assigned for unsubstituted ring B protons. H-3 proton in the three compounds appears as singlets in the range $\delta_{\mathrm{H}} 6.40-6.74 \mathrm{ppm}$. Protons at positions 5 and 6 appears as two ortho coupled doublets. $\mathrm{H}-5$ appears at $\delta_{\mathrm{H}} 8.09(\mathrm{~d}, J=8.6 \mathrm{~Hz}), 8.03(\mathrm{~d}, J=8.8 \mathrm{~Hz})$ and $7.69(\mathrm{~d}, J=8.5 \mathrm{~Hz}) \mathrm{ppm}$, while H-6 appears at $\delta_{\mathrm{H}} 6.88(\mathrm{~d}, J=8.6 \mathrm{~Hz}), 6.86(\mathrm{~d}, J=8.8 \mathrm{~Hz})$ and $6.84(\mathrm{~d}, J=8.5 \mathrm{~Hz}) \mathrm{ppm}$ in $\mathbf{1}, 4$ and $\mathbf{5}$ respectively (Table 1$)$. In the ${ }^{13} \mathrm{C}-\mathrm{NMR}$ the chemical shift of C-7 $\left(\delta_{\mathrm{C}} 165.84,163.17\right.$ and $\left.166.44 \mathrm{ppm}\right)$ and C-8 $\left(\delta_{\mathrm{C}} 112.71,107.65\right.$ and $\left.115.13 \mathrm{ppm}\right)$ in $\mathbf{1}, \mathbf{4}$ and $\mathbf{5}$ respectively (Table 2) were diagnostic for C-7 oxygenation and C-8 alkylation. 
ESI-HRMS of 1 showed $[\mathrm{M}+1]^{+}$at $\mathrm{m} / z$ 337.1064, [M+Na] $]^{+}$at $\mathrm{m} / z 359.0882$ and $[\mathrm{M}-1]^{+}$at $\mathrm{m} / \mathrm{z}$ 335.0935 for the molecular formula $\mathrm{C}_{20} \mathrm{H}_{18} \mathrm{O}_{5}$ indicating 5 additional carbons over the flavone skeleton. ${ }^{1} \mathrm{H}-\mathrm{NMR}$ and ${ }^{13} \mathrm{C}-\mathrm{NMR}$ showed signals for an acetyl group at $\delta_{\mathrm{H}} 2.00(\mathrm{~s}) ; \delta_{\mathrm{C}} 170.84$ and $20.84 \mathrm{ppm}$. The three left carbons arranged in $\mathrm{OCH}_{2}-\mathrm{CH}_{-} \mathrm{CH}_{2}-\mathrm{O}$ spin system as indicated by COSY, HSQC and $\mathrm{H} 2 \mathrm{BC}$ experiments. Due to the overlap of these protons in the $\mathrm{CDCl}_{3}$ proton spectrum the sample was measured in $\mathrm{C}_{6} \mathrm{D}_{6}$. The oxygenated methylene at $\delta_{\mathrm{H}} 4.16(\mathrm{t}, J=9.0 \mathrm{~Hz}), 4.22(\mathrm{dd}, J=4.9$, $9.2 \mathrm{~Hz}) ; \delta_{\mathrm{C}} 75.62 \mathrm{ppm}$ as well as the methine at $\delta_{\mathrm{H}} 3.5 \mathrm{~m} ; \delta_{\mathrm{C}} 40.04 \mathrm{ppm}$ were assigned to a heterocyclic five membered ring including $\mathrm{C}-7$ and $\mathrm{C}-8$. HMBC experiment showed correlations between the two methylene protons and C-7 at $\delta_{\mathrm{C}} 165.43 \mathrm{ppm}$. While the second methylene at $\delta_{\mathrm{H}} 3.80$ (bt, $J=10.7 \mathrm{~Hz}), 4.47(\mathrm{dd}, J=4.3,11.0 \mathrm{~Hz}) ; \delta_{\mathrm{C}} 63.91 \mathrm{ppm}$ was the site of acetylation as indicated from the HMBC correlation between its protons signals and the carbonyl signal at $\delta_{\mathrm{C}} 170.84 \mathrm{ppm}$. The data of compound $\mathbf{1}$ enable the identification of the structure as a new natural product given the name tephropurpugazanin.<smiles>CC(=O)OCC1COc2ccc3c(=O)cc(-c4ccccc4)oc3c21</smiles><smiles>COc1ccc2c(=O)cc(-c3ccccc3)oc2c1C1=C(O)C(C)(C)[Te]C1=O</smiles>

4<smiles></smiles><smiles>CC(C)(O)C(O)C1COc2ccc3c(=O)cc(-c4ccccc4)oc3c21</smiles><smiles>COc1ccc(-c2oc3c(OC)c(O)ccc3c(=O)c2O)cc1</smiles><smiles></smiles>

Figure 1. Structures of the isolated compounds

Both ${ }^{1} \mathrm{H}-\mathrm{NMR}$ and ${ }^{13} \mathrm{C}-\mathrm{NMR}$ of 4 indicated the presence of methoxyl group at $\delta_{\mathrm{H}} 3.73 \mathrm{~s} ; \delta_{\mathrm{C}}$ $56.61 \mathrm{ppm}$ assigned for C-7. In addition, ${ }^{1} \mathrm{H}-\mathrm{NMR}$ showed singlet at $\delta_{\mathrm{H}} 1.45$ integrated for 6 protons correlated by HSQC experiment to $\delta_{\mathrm{C}} 25.83 \mathrm{ppm}$ assigned for two germinal methyl groups. ${ }^{13} \mathrm{C}-\mathrm{NMR}$ revealed the presence of 4 quaternary carbons at $\delta_{C} 85.02,124.16,160.04$ and $170.70 \mathrm{ppm}$ assigned for fully substituted $\alpha, \beta$-unsaturated five membered lactone ring. Comparison of the data of $\mathbf{4}$ with those reported for apollinin [16] indicated that $\mathbf{4}$ is the C-4" hydroxyl derivative of apollinin. HRESIMS showed $[\mathrm{M}+1]^{+}$at $\mathrm{m} / \mathrm{z} 379.1172,[\mathrm{M}+\mathrm{Na}]^{+}$at $\mathrm{m} / \mathrm{z} 401.0995$ and $[\mathrm{M}-1]^{+}$at $\mathrm{m} / \mathrm{z} 377.1025$ for the molecular formula $\mathrm{C}_{22} \mathrm{H}_{18} \mathrm{O}_{6}$. Ions due to the loss of one oxygen atom were recorded at $\mathrm{m} / \mathrm{z}$ $363.1220\left(\mathrm{C}_{22} \mathrm{H}_{18} \mathrm{O}_{5}+\mathrm{H}\right)$ and at $\mathrm{m} / z 385.1038\left(\mathrm{C}_{22} \mathrm{H}_{18} \mathrm{O}_{5}+\mathrm{Na}\right)$. From the above discussion 4 was identified as the previously unreported 4"-hydroxyapollinin. Apollinin was reported as structural isomer for tephroglabrin [16, 17]. Critically, the reported ${ }^{1} \mathrm{H}-\mathrm{NMR}$ data for apollinin [16] assigned H$4^{\prime \prime}$ at $\delta_{\mathrm{H}} 7.53 \mathrm{ppm}$ a position overlapped with $2^{\prime}, 4^{\prime}, 6^{\prime}-$ protons at $\delta_{\mathrm{H}} 7.43-7.55 \mathrm{ppm}$ which make the presence of this proton questionable. In addition, the reported chemical shift of C-4" at $\delta_{\mathrm{C}} 159.9 \mathrm{ppm}$ is very odd for non-oxygenated carbon atom. The MS data were recorded using EIMS mode were the loss of hydroxyl group on quaternary carbons is very common. Consequently, apollinin in the reference [16] was most likely the same as $\mathbf{4}$ and its structure must be revised. Similarly, the carbon 
value of the $=\mathrm{CH}$ carbon as part of the 5-membered hetero cyclic ring in tephroglabrin at $\delta_{\mathrm{C}}$ $175.8 \mathrm{ppm}$ [17] is more than $20 \mathrm{ppm}$ off the expected value. This structure needs careful revision.

The $\mathrm{C}_{21} \mathrm{H}_{20} \mathrm{O}_{5}$ molecular formula was obtained for both 5 and 6. The ${ }^{1} \mathrm{H}-\mathrm{NMR}$ and ${ }^{13} \mathrm{C}-\mathrm{NMR}$ data of the two compounds were very similar to that reported for tephroapollin E [18].

Compound $\mathbf{2}$ compared to $\mathbf{5}$ and $\mathbf{6}$ bears extra hydroxyl group and one acetyl group. The HRESIMS showed an $[\mathrm{M}+1]^{+}$at $\mathrm{m} / z 411.1436$ for the molecular formula $\mathrm{C}_{23} \mathrm{H}_{22} \mathrm{O}_{7}$ were in support of the additional substituents. The disappearance of H-5 proton and presence of $\mathrm{H}-6$ proton as singlet at $\delta_{\mathrm{H}} 6.14 \mathrm{ppm}$ in addition to the carbon signal at $\delta_{\mathrm{C}} 163.76 \mathrm{ppm}$ all pointed out to oxygenated C-5. The $\mathrm{H}-4^{\prime \prime}$ proton appears at $\delta_{\mathrm{H}} 3.83(\mathrm{~d}, J=8.5 \mathrm{~Hz})$ in 5 and at $\delta_{\mathrm{H}} 5.55(\mathrm{~s})$ in 2 indicating that $\mathrm{C}-4^{\prime \prime}$ is the site of acetylation. The data of $\mathbf{2}$ is closely similar to the literature data of tephropurpulin A [19].

Table 1. ${ }^{1} \mathrm{H}-\mathrm{NMR}$ data $(\delta \mathrm{ppm}, J$ in parentheses in $\mathrm{Hz}) *$ of compounds 1, 2, 4-6a*

\begin{tabular}{|c|c|c|c|c|c|c|}
\hline Pos & & 1 & 2 & 4 & 5 & $6 \mathbf{a}$ \\
\hline & $\mathrm{CDCl}_{3}$ & $C_{6} D_{6}$ & $\mathrm{CD}_{3} \mathrm{OD}$ & $\mathrm{CDCl}_{3}$ & $\mathrm{CDCl}_{3}$ & $\mathrm{CDCl}_{3}$ \\
\hline 3 & $6.74(\mathrm{~s})$ & $6.73(\mathrm{~s})$ & $6.65(\mathrm{~s})$ & $6.52(\mathrm{~s})$ & $6.40(\mathrm{~s})$ & $6.77(\mathrm{~s})$ \\
\hline 5 & $8.09(\mathrm{~d}, 8.6)$ & $8.33(\mathrm{~d}, 8.8)$ & - & $8.03(\mathrm{~d}, 8.8)$ & $7.69(\mathrm{~d}, 8.5)$ & $8.11(\mathrm{~d}, 8.5)$ \\
\hline 6 & $6.88(\mathrm{~d}, 8.6)$ & $6.62(\mathrm{~d}, 8.8)$ & $6.14(\mathrm{~s})$ & $6.86(\mathrm{~d}, 8.8)$ & $6.84(\mathrm{~d}, 8.5)$ & $6.87(\mathrm{~d}, 8.5)$ \\
\hline $2^{\prime}, 6^{\prime}$ & $7.89(\mathrm{~m}, 2 \mathrm{H})$ & $7.68(\mathrm{~d}, 7.8,2 \mathrm{H})$ & $7.93(\mathrm{~d}, 7.5,2 \mathrm{H})$ & $7.54(\mathrm{~d}, 6.9)$ & $7.77(\mathrm{~d}, 8.5)$ & $7.95(\mathrm{~d}, 6.7,2 \mathrm{H})$ \\
\hline $\begin{array}{l}3^{\prime}, 5^{\prime} \\
\prime^{\prime}\end{array}$ & $7.52(\mathrm{~m}, 3 \mathrm{H})$ & $7.15 \mathrm{~m}$ & $7.53(\mathrm{~d}, 7.3,2 \mathrm{H})$ & $7.27(\mathrm{~m})$ & $7.37(t, 7.4)$ & $7.55 \mathrm{~m}$ \\
\hline $\begin{array}{l}4 \\
2^{\prime \prime}\end{array}$ & 4.69 (Overl) & $\begin{array}{c}.08(\mathrm{t}, 1.4,2 \mathrm{H}) \\
4.16(\mathrm{t}, 9)\end{array}$ & $\begin{array}{l}7.3 /(\mathrm{t}, 1.3) \\
4.73(\mathrm{t}, 9.6)\end{array}$ & - & $\begin{array}{l}1.45(\mathrm{t}, 1.4) \\
4.69(\mathrm{t}, 8.4)\end{array}$ & $4.84(\mathrm{t}, 9.7)$ \\
\hline & $4.80(\mathrm{t}, 9.3)$ & $4.22(\mathrm{dd}, 4.9,9.2)$ & $5.10(\mathrm{q}, 5)$ & & $4.79(\mathrm{~d}, 8.7)$ & $5.22(\mathrm{q}, 5.6)$ \\
\hline $3^{\prime \prime}$ & 4.16 (Overl) & $3.5(\mathrm{~m})$ & $4.25(\mathrm{q}, 5)$ & - & $4.10(t, 7)$ & $4.43(\mathrm{q}, 5.6)$ \\
\hline $4^{\prime \prime}$ & $\begin{array}{l}4.19 \text { (Overl) } \\
4.69 \text { (Overl) }\end{array}$ & $\begin{array}{c}3.80(\mathrm{bt}, 10.7) \\
4.47(\mathrm{dd}, 4.3,11)\end{array}$ & $5.55(\mathrm{~s})$ & - & $3.83(\mathrm{~d}, 8.5)$ & $5.74(\mathrm{~s})$ \\
\hline Gem & - & - & $1.24(\mathrm{~s})$ & $1.45(\mathrm{~s}, 6 \mathrm{H})$ & $1.41(\mathrm{~s})$ & $1.35(\mathrm{~s})$ \\
\hline $2 \mathrm{CH}_{3}$ & & & $1.39(\mathrm{~s})$ & & $1.42(\mathrm{~s})$ & $1.49(\mathrm{~s})$ \\
\hline $\mathrm{COCH}_{3}$ & $2.00(\mathrm{~s})$ & $1.52(\mathrm{~s})$ & $1.87(\mathrm{~s})$ & - & - & $1.92(\mathrm{~s})$ \\
\hline $\mathrm{OCH}_{3}$ & - & - & - & $3.73(\mathrm{~s})$ & - & - \\
\hline
\end{tabular}

*Assignments based on COSY, HSQC, HMBC, H2BC and comparison with literature data for known compounds.

The relative stereochemistry of compounds $\mathbf{2 , 5}$ and $\mathbf{6}$ were accessed based of their spectral characters. The single bond between $\mathrm{C}-3$ " and C-4" allows free rotation and the existence of conformational isomers. The existence of $\mathbf{2 , 5}$ and $\mathbf{6}$ as pure rotamer indicating that the energy barrier for the interconversion of one conformer to another is high enough to restrict the free rotation. The possible conformers A-C are shown in figure 2. Conformer $\mathrm{C}$ is very unlikely due to the high steric hindrance with the aromatic system. In case of conformer A the dihedral angle between $\mathrm{H}-3^{\prime \prime}$ and $\mathrm{H}-4$ " is closer to $70^{\circ}$ consequently $\mathrm{H}-4^{\prime \prime}$ appears as singlet in $\mathbf{2}$ and $\mathbf{6}\left(3^{\prime \prime} R, 4^{\prime \prime} S\right)$. The dihedral angle in conformer B is about $168^{\circ}$ leading to the appearance of $\mathrm{H}-4^{\prime \prime}$ as doublet $(J=8.5 \mathrm{~Hz})$ in $\mathbf{5}\left(3^{\prime \prime} R, 4^{\prime \prime} R\right)$. $3 \mathrm{D}$ model of conformer A revealed a short distance in space between $\mathrm{H}-4^{\prime \prime}$ and the two equivalents $\mathrm{H}-$ 2'and H-6' aromatic protons. This fact was confirmed by the ROESY experiment results, where nOe correlation was observed between these protons (Supporting data). Conformer B model showed that $\mathrm{H}-4$ " is directed in space away from the aromatic protons consequently no nOe correlation were observed. Other than The COSY correlations ROESY data did not provide additional evidences.

Structure similar to $\mathbf{2}$ was reported under the two names tephropurpulin A and 5hydroxytephroapollin F [19-20]. Tephroapollin F was reported from T. apollinea with negative optical rotation and $\mathrm{H}-4$ " signal as doublet $\left(\delta_{\mathrm{H}} 5.08, J=9 \mathrm{~Hz}\right)$. Consequently, the name 5-hydroxytephroapollin $\mathrm{F}$ is inappropriate as the data of this reported compound showed positive optical rotation and $\mathrm{H}-4$ " proton as singlet at $\delta_{\mathrm{H}} 5.61 \mathrm{ppm}$ [19]. Tephropurpulin A has very weak positive optical rotation and $\mathrm{H}-$ 4 " signal appears as broad singlet and might be in fact racemic mixture. As compound 2 showed strong negative optical rotation $\left(-304.4^{\circ}\right)$ and $\mathrm{H}-4^{\prime \prime}$ signal appears as singlet at $\delta_{\mathrm{H}} 5.55 \mathrm{ppm}$ it was described as the antipode of tephropurpulin A and given the name (-)-tephropurpulin A reported for the first time from natural source. 
Table 2. ${ }^{13} \mathrm{C}-\mathrm{NMR}$ data of compounds 1, 2, 4-6a ${ }^{*}$

\begin{tabular}{cccccccc}
\hline Pos & & $\mathbf{1}$ & $\mathbf{2}$ & $\mathbf{3}$ & $\mathbf{4}$ & $\mathbf{5}$ & $\mathbf{6 a}$ \\
\hline & $\mathbf{C D C l}_{\mathbf{3}}$ & $\mathbf{C}_{\mathbf{6}} \mathbf{D}_{\mathbf{6}}$ & $\mathbf{C D}_{\mathbf{3}} \mathbf{0 D}$ & $\mathbf{D M S O}$ & $\mathbf{C D C l}_{\mathbf{3}}$ & $\mathbf{C D C l}_{\mathbf{3}}$ & $\mathbf{C D C l}_{\mathbf{3}}$ \\
\hline 2 & 162.54 & 161.53 & 162.90 & 151.14 & 161.70 & 163.01 & 162.65 \\
3 & 107.53 & 107.78 & 104.78 & 133.98 & 107.28 & 106.14 & 107.80 \\
4 & 177.63 & 176.20 & 182.30 & 175.24 & 177.73 & 178.11 & 177.82 \\
5 & 128.48 & 128.53 & 163.76 & 121.24 & 128.08 & 127.83 & 128.26 \\
6 & 109.03 & 108.49 & 93.47 & 115.72 & 109.36 & 108.94 & 108.47 \\
7 & 165.84 & 165.43 & 167.32 & 155.26 & 163.17 & 166.44 & 165.65 \\
8 & 112.71 & 112.68 & 104.38 & 135.15 & 107.65 & 115.13 & 118.18 \\
9 & 154.06 & 153.89 & 153.11 & 153.56 & 154.84 & 154.99 & 154.08 \\
10 & 118.43 & 119.03 & 104.55 & 117.88 & 117.98 & 117.78 & 113.60 \\
$1^{\prime}$ & 131.67 & 131.98 & 130.94 & 123.41 & 131.86 & 131.58 & 132.27 \\
$2^{\prime} 6^{\prime}$ & 126.13 & 125.97 & 126.19 & 130.57 & 126.19 & 126.16 & 126.21 \\
$3^{\prime}, 5^{\prime}$ & 129.19 & 128.79 & 128.87 & 114.09 & 129.00 & 128.89 & 129.05 \\
$4^{\prime}$ & 131.59 & 130.85 & 131.88 & 159.45 & 131.55 & 131.36 & 131.40 \\
$2^{\prime \prime}$ & 76.17 & 75.62 & 73.79 & - & 170.70 & 77.84 & 73.65 \\
$3^{\prime \prime}$ & 40.17 & 40.04 & 39.77 & - & 124.16 & 42.92 & 40.74 \\
$4^{\prime \prime}$ & 64.39 & 63.91 & 77.13 & - & 160.04 & 79.08 & 76.75 \\
$5^{\prime \prime}$ & - & - & 71.44 & - & 85.02 & 73.24 & 70.97 \\
$\mathrm{Gem}_{2}$ & - & - & 25.61 & - & 25.83 & 25.84 & 27.25 \\
$\mathrm{CH}_{3}$ & & & 26.11 & & $(2 X)$ & 26.64 & 27.39 \\
$\mathrm{COCH}_{3}$ & 170.84, & 169.62, & 170.85, & $\mathbf{8}-\mathrm{OCH}_{3} 61.26$ & - & - & 169.89 \\
& 20.84 & 19.90 & 19.06 & $\mathbf{4}^{\prime}-\mathrm{OCH}$ & & & 20.41 \\
$\mathrm{OCH}_{3}$ & - & - & - & 55.60 & & & \\
& & - & - & - & 56.61 & - & -
\end{tabular}

*Assignments based on COSY, HSQC, HMBC, H2BC and comparison with literature data for known compounds.<smiles>CC(C)(O)C1C2CC3CC(C(O)C3C2C=O)C1c1ccccc1</smiles><smiles>[R20]C([C@@H]1COC(=C)/C1=C\C)C(O)([18OH])[18OH]</smiles>

2: $\mathrm{R}=\mathrm{COCH}_{3}$ 6: $\mathrm{R}=\mathrm{OH}$

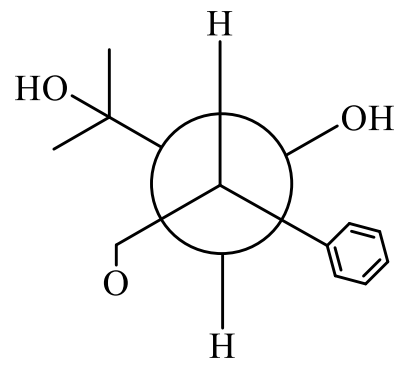

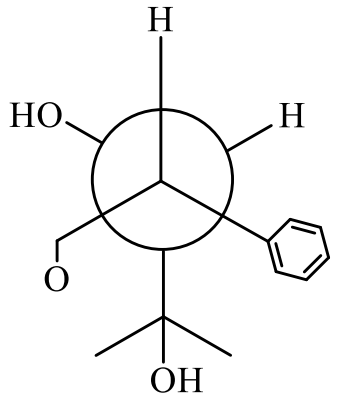<smiles>C=C1O[C][C@H]([C@@H](C)O)/C1=C/C</smiles>

5

Figure 2. Possible conformers of compounds $\mathbf{2 , 5}$ and $\mathbf{6}$ 
Compound 5 expressed positive sign in optical rotation $\left(+94.2^{\circ}\right)$ and $\mathrm{H}-4^{\prime \prime}$ signal appears as doublet at $\delta_{\mathrm{H}} 3.83 \mathrm{ppm}(\mathrm{J}=8.5 \mathrm{~Hz})$ indicating that the $\mathrm{H}-3^{\prime \prime}$ and $\mathrm{H}-4^{\prime \prime}$ have anti conformation. The similar structure known as tephroapollin E was reported to have negative optical rotation and $\mathrm{H}-4^{\prime \prime}$ signal as broad singlet indicating the syn orientation of H-3" and H-4" [18]. Compound 5 has similar relative configuration to polystachin as they share the positive optical rotation and appearance of $\mathrm{H}-4^{\prime \prime}$ as doublet [21]. Compound $\mathbf{5}$ was given the name epi-tephroapollin E reported for the first time from natural source.

The data of $\mathbf{6}$ is identical with those reported for tephroapollin E [18]. Comparison of the ${ }^{13} \mathrm{C}$ NMR data of 5 and 6 revealed a significant difference in the chemical shifts of C-2" and C-4" (Supporting data). In 5, C-2" and C-4" chemical shifts were $\delta_{\mathrm{C}} 77.84,79.08$, while in 6 the corresponding chemical shifts were $\delta_{\mathrm{C}} 72.90$ and $75.99 \mathrm{ppm}$, respectively. These significant differences in addition to splitting pattern of $\mathrm{H}-4$ " can furnish effective tools for the differentiation between these epimers. CD data of $\mathbf{2}, \mathbf{5}$ and $\mathbf{6}$ revealed similarities between $\mathbf{2}$ and $\mathbf{6}$ where negative cotton effects were observed at 271 and $259 \mathrm{~nm}$ respectively. On the other hand, $\mathbf{5}$ showed positive cotton effect at $258 \mathrm{~nm}$. Acetylation of $\mathbf{6}$ resulted in the formation monoacetyl products $\mathbf{6 a}$ clearly different from tephroapollin F (Supporting data) and could be described as the non-reported epitephroapollin F [18]. However, it was not isolated naturally from the plant.

Compound 3 was identified by comparison of its data with those reported for 3,7-dihydroxy-8methoxy-2-(4-methoxyphenyl)-4H-1-benzopyran-4-one isolated from Lolium multiflorum ponce et al [22].

Tephrosia species are rich in flavonoid derivatives. Review of the secondary metabolites from 1911- 2014 indicated that 161 flavonoid derivatives were reported from the Genus. Among these thirty-one prenylated flavones including sixteen 5-dexoyflavones were identified [14]. Further investigation of the Genus indicated the presences of prenylated flavonos 5-deoxy derivatives in $T$. egregia, T. tinctoria, T. apollinea and T. purpurea [4, 10, 18, 20, 23, 24]. Due to the restricted distribution of prenylated flavonos 5-deoxy derivative they can be considered as taxonomic markers to the Genus Tephrosia.

\section{Acknowledgments}

The authors are thankful to Deanship of Scientific Research (DSR), Prince Sattam bin Abdulaziz University, Al-Kharj, Saudi Arabia for providing the fund to carry out this study under research grants No. 17033/03/2020.

\section{Supporting Information}

Supporting information accompanies this paper on http://www.acgpubs.org/journal/records-ofnatural-products

\section{ORCID}

Maged S. Abdel-Kader: 0000-0002-5128-2656

Mohammed H. Alqarni: $\underline{0000-0002-7061-9111}$

Ahmed I. Foudah: 0000-0002-6728-8614

\section{References}

[1] D. W. Gakuya, S. M. Itonga, J. M. Mbaria, J. K. Muthee and J. K. Musau (2013). Ethnobotanical survey of biopesticides and other medicinal plants traditionally used in Meru central district of Kenya, $J$. Ethnopharmacol. 145, 547-553.

[2] S. Khatoon, V. Rai, A. K. Rawat and S. Mehrotra (2006). Comparative pharmacognostic studies of three Phyllanthus species, J. Ethnopharmacol. 104, 79-86.

[3] P. Pamu, M. Shanmugam and S. Sethupathy (2017). Beneficial Effects of Tephrosia purpurea Ethanolic seed extract on lipids and membrane bound enzymes in experimental diabetic rats, J. Young Pharm. 9, 550-554. 
[4] A. Shukla and P. Mourya (2016). Investigations for anti-urolithiatic activity of roots against Tephrosia purpurea ethylene glycol-induced renal calculi in rats, Asian J. Pharm. Pharmacol. 2, 40-43.

[5] J. R. Daddam, M. Rao and D. S. Rao (2015). Studies on Tephrosia purpurea. A phytochemical screening and antimicrobial studies. I.J.P.A.E.S. 5(4), 106-109.

[6] M. Avula, A. Somasekhar, A. Sumanjali, B. Kumar, B. Prasanna, T. Vali and D. Bhargavi (2014). Anticancer activity of Tephrosia purpurea root extracts against Ehrlich Ascites Carcinoma (EAC) cells in swiss albino mice, der Pharmacia Sinica. 5(2), 81-87.

[7] S. Lodhi, A. P. Jain, V. K. Sharma and A. K. Singhai (2013). Wound-healing effect of flavonoid-rich fraction from Tephrosia purpurea Linn. on streptozotocin-induced diabetic rats, J. Herbs Spices Med. Plants. 19(2), 191-205.

[8] M. Mujeeb, R. Zafar, A. Husain and A. Ahmad (2012). Antihepatotoxic activity of aqueous extracts of callus culture of Tephrosia purpurea (L) pers, Acta Pol. Pharm. 69, 545-549.

[9] R. K. Diwan and R. C. Saxena (2010). Insecticidal property of flavonoid isolated from Tephrosia Purpuria, Int. J. Chem. Sci. 8, 777-782.

[10] A. Sallam, A. Mira, M. A. Sabry, O. B. Abdel-Halim, S. R. Gedara and A. A. Galala (2020). New prenylated flavonoid and neuroprotective compounds from Tephrosia purpurea subsp. dunensis, Nat. Prod. Res. Sep 2:1-9. doi: 10.1080/14786419.2020.1815739.

[11] Y. Atilaw, L. Muiva-Mutisya, A. Ndakala, H. M. Akala, R. Yeda, Y. J. Wu, P. Coghi, V. K. W. Wong, M. Erdélyi and A. Yenesew (2017). Four prenylflavone derivatives with antiplasmodial activities from the stem of Tephrosia purpurea subsp. leptostachya, Molecules 22.1514 (9 pages). doi:10.3390/molecules22091514

[12] W. P. Juma, H. M. Akala, F. L. Eyase, L. M. Muiva, M. Heydenreich, F. A. Okalebo, P. M. Gitu, M. G. Peter, D. S. Walsh, M. Imbuga and A. Yenesew (2011). Terpurinflavone: An antiplasmodial flavone from the stem of Tephrosia Purpurea, Phytochem. Lett. 4, 176-178.

[13] R. N. Yadava and P. Yadav (2014). Acute diutrtic activity of a new flavone glycoside from the stems of Tephrosia purpurea Linn. in nornal rats, World J. Pharm. Res. 3(4), 1558-1568.

[14] Y. Chen, T. Yan, C. Gao, W. Cao and R. Huang (2014). Natural Products from the Genus Tephrosia, Molecules 19, 1432-1458.

[15] P. P. Dalwadi, J. L. Patel and P. V. Patani (2014). Tephrosia purpurea Linn (Sharpunkha, Wild Indigo): A review on phytochemistry and pharmacological studies, Indian J. Pharm. Biol. Res. 2(1), 108-121.

[16] P. Waterman and S. Khalid (1980). The major flavonoids of the seed of Tephrosia apollinea, Phytochemistry 19, 909-915.

[17] A. Pelter, R. S. Ward, E. V. Rao and N. R. Raju, (1981). 8-Substituted flavonoids and 3'-substituted 7oxygenated chalcones from Tephrosia purpurea, J. Chem. Soc. Perkin 1, 2491-2498.

[18] M. H. Abdel-Razek, A. E. Mohamed and A. Ahmed (2007). Prenylated flavonoids from Tephrosia apollinea, Heterocycles 71, 2477-2490.

[19] M.E. F. Hegazy, M. H. Abd El-Razek, F. Nagashima, Y. Asakawa and P. W. Paré (2009). Rare prenylated flavonoids from Tephrosia purpurea, Phytochemistry 70, 1474-1477.

[20] A. K. Khalafallah, S. A. Suleiman, A. H. Yousef, N. A. A. El-kanzi and A. H. Mohamed (2009). Prenylated flavonoids from Tephrosia apollinea, Chin. Chem. Lett. 20, 1465-1468.

[21] R. Vleggaar, T. M. Smalberger and J. L. van Aswegen (1978). Flavonoids from Tephrosia. X. Structure of polystachin, S. Afr.J. Chem. 31(2), 47- 50.

[22] M. A. Ponce, M. J. Bompadre, J. M. Scervino, J. A. Ocampo, E. J. Chaneton and A. M. Godeas (2009). Flavonoids, benzoic acids and cinnamic acids isolated from shoots and roots of Italian rye grass (Lolium multiflorum Lam.) with and without endophyte association and arbuscular mycorrhizal fungus, Biochem. Syst. Ecol. 37(4), 245- 253.

[23] M. V. S. Teixeira, J. Q. Lima, A. T. A. Pimenta, F. R. L. da Silva, M. C. F. de Oliveira, I. G. Pereira, D. C. Costa-Junior, P. R. V. Ribeiro, G. M. P. Santiago, M. A. S. Lima, R. Braz-Filho, M. M. Berzerra, R. C. Montenegro, D. D. Rocha, M. E. A. de Moraes, A. C. de Medeiros and A. M. C. Arriaga (2018). New flavone and other compounds from Tephrosia egregia: assessing the cytotoxic effect on human tumor cell lines, Rev. Bras. Farmacogn. 28(3), 333-338.

[24] G. R. Reddy, A. Rhammohan, R. Munikishore and D. Gunasekar, (2014). A new 5-deoxyflavonol from Tephrosia tinctoria, J. Chem. Pharm. Res. 6(9), 34-36.

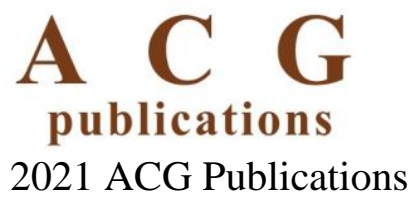

